\title{
ESP's Tank 42 Washwater Transfer to the 241-F/H Tank Farms
}

by

C. I. Aponte

Westinghouse Savannah River Company

Savannah River Site

Aiken, South Carolina 29808

E. D. Lee

Westinghouse Savannah River Col

SC US

This paper was prepared in connection with work done under the above contract number with the U.S.

Department of Energy. By acceptance of this paper, the publisher and/or recipient acknowledges the U. S. Government's right to retain a nonexclusive, royalty-free license in and to any copyright covering this paper, along with the right to reproduce and to authorize others to reproduce all or part of the copyrighted paper. 


\section{DISCLAIMER}

This report was prepared as an account of work sponsored by an agency of the United States Government. Neither the United States Government nor any agency thereof, nor any of their employees, makes any warranty, express or implied, or assumes any legal liability or responsibility for the accuracy, completeness, or usefulness of any information, apparatus, product, or process disclosed, or represents that its use would not infringe privately owned rights. Reference herein to any specific commercial product, process, or service by trade name, trademark, manufacturer, or otherwise does not necessarily constitute or imply its endorsement, recommendation, or favoring by the United States Government or any agency thereof. The views and opinions of authors expressed herein do not necessarily state or reflect those of the United States Government or any agency thereof.

This report has been reproduced directly from the best available copy.

Available to DOE and DOE contractors from the Office of Scientific and Technical Information, P. O. Box 62, Oak Ridge, TN 37831; prices available from (423) 576-8401.

Available to the public from the National Technical Information Service, U. S. Department of Commerce, 5285 Port Royal Road, Springfield, VA 22161. 


\section{DISCLAIMER}

Portions of this document may be illegible electronic image products. Images are produced from the best available original document. 


\section{WASTE PRE-TREATMENT ENGINEERING PROCESS ENGINEERING}

WSRC-TR-97-00394 REVISION: 0

Keywords:

WCP, ESP

Tank 42, Transfer

Washwater

ESP's Tank 42 Washwater Transfer to the 241-F/H Tank Farms

by

Retention:

Permanent

Ernest D. Lee and C. I. Aponte

Classification: $U$

Does not Contain UCNI r.R. Hester $12 / 8 / 97$

ADC/RO

Issued: December 1997

APPROVALS

Cinent Ddee / C.U. Bpoute

E. D. Lee, WPTE / C. I. Aponte, CSTE, Co-authors

Date: $12 / 5 / 97$

Yllar

$R Q$

eeunar/

Date: $12 / 5197$

G. R. Beaumier, Technical Reviewer WPTE

थय.

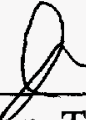

M. E. Jamison, Technical Reviewer CSTE

Date: $12 / 5 / 97$

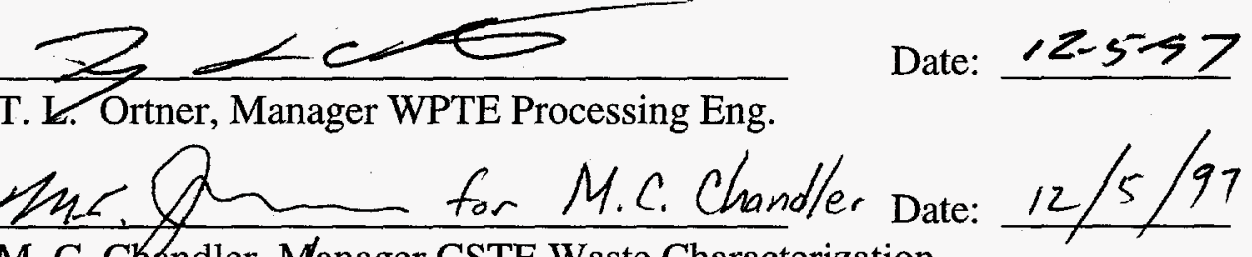

M. C. Changler, Manager CSTE Waste Characterization

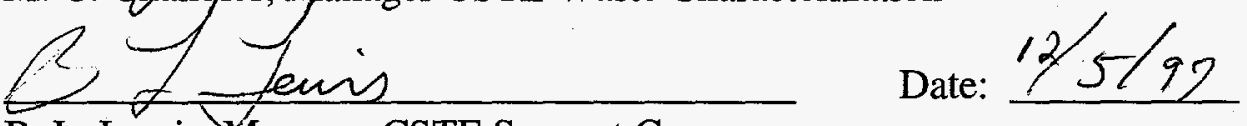

B. L. Lewis, Manager CSTE Support Group

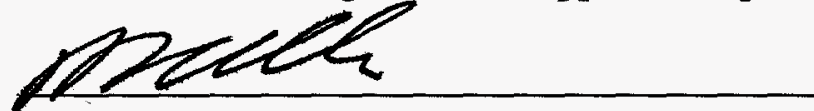

Date: $: 2-5-9>$

M. S. Miller, Manager WPTE

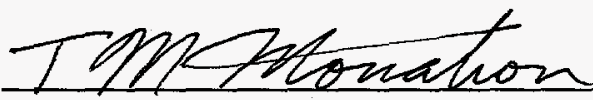

Date: $12-5-97$

T. M. Monahon, Manager CSTE 


\section{Table of Content}

1. Summary 3

1.1 Summary of Requirements........................................................................................................

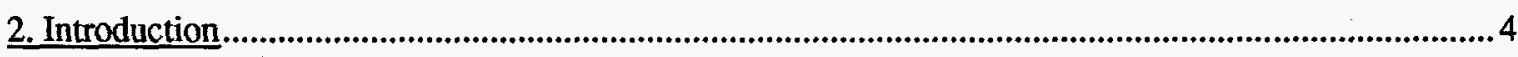

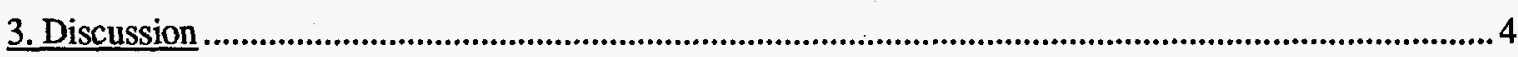

3.1 The Waste Stream Categories and Characterizations....................................................................... 4

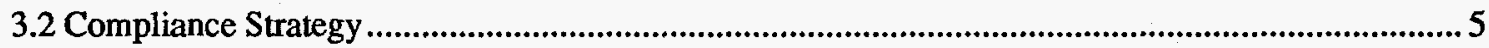

3.3 Specific Criteria for Tank 42 Washwater Decant.............................................................................. 5

3.3.1 Evaluation for the Hydrogen Generation Rate and the 242-16H Evaporator Radiological

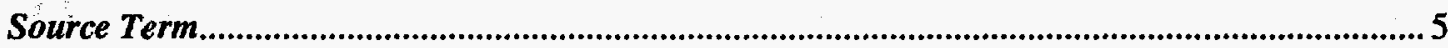

3.3.2 Requirements for Corrosion Prevention .......................................................................6

3.3.3 Requirements to Prevent Accumulation of Flammable/Explosive Species.............................. 7

3.3.4 Requirement For Radionuclide Content ........................................................................

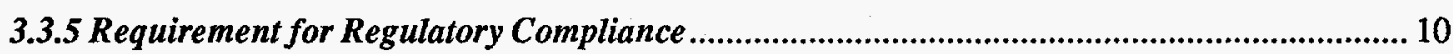

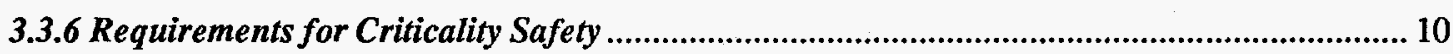

3.3.7 Requirement for Compatibility with the Tank Farm's Authorization Basis .......................... 10

3.3.8 Requirement to Satisfy Downstream Facility Acceptance Criteria .......................................... 10

3.4 ITP Detection of Leak from Valve-box by VAMP ........................................................................... 11

3.5 H-Tank Farm Detection of Leak from Valve-box by VAMP...................................................... 11

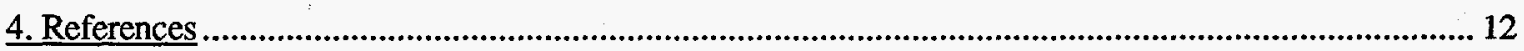

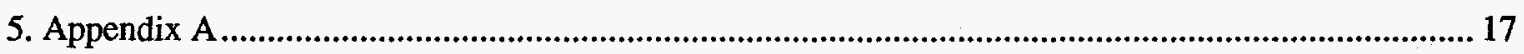

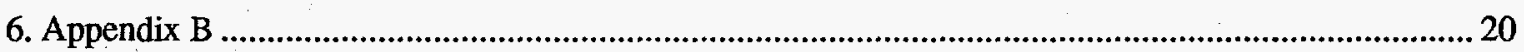

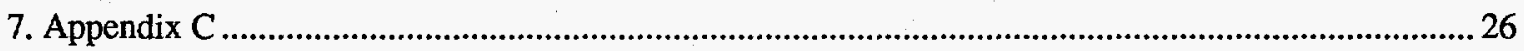

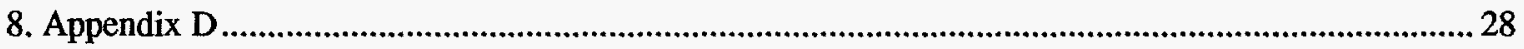

Table of Tables

Table 1. Summary of RST Limits for H-Tank Farm .3

Table 2. Tank 42 Slurry Sample Results, ESP-190_................................................................... 14

Table 3. Tank 42 Washwater Analytical Results, ESP-191 ............................................................ 15

Table 4. CST's WAC Listed Corrosive Species Comparison ................................................................. 15

Table 5. Tank 42 Inhalation Dose Species in Washwater ...................................................................... 16

Table 6. Tank 42 Inhalation Dose Species in Sludge Insoluble Solids ................................................ 16 


\section{Summary}

This report addresses requirements for transfers of ESP decants to CSTE's 242-16H evaporator system (i.e., Tank 43) and Tank 22 (i.e., Type IV waste tank). The requirements are provided in CSTE's Waste Acceptance Criteria (ref. 1) and Tank Farm Authorization Basis. The bounding radiological inhalation dose is expected to be less than $3 E+06 \mathrm{rem} / \mathrm{gal}$ for the ESP washwater. This waste transfer will comply with all of the Tank Farm WAC requirements. The bounding washwater volume that is planned to be transferred to the H-Tank Farm is $300 \mathrm{kgal}$. The receipt tank for the ESP wash water will have a maximum supernate temperature of $49^{\circ} \mathrm{C}$ until the next chemistry sample is taken and evaluated to determine the appropriate temperature limit.

Table 1. Summary of Radiological Source Term (RST) Limits for H-Tank Farm

\begin{tabular}{|c|c|c|c|}
\hline Waste Stream & $\begin{array}{c}\text { RST } \\
\left(\mathbf{r e m}_{\text {int }} \text { gallon) }\right.\end{array}$ & $\begin{array}{c}\text { Factor Below RST } \\
\text { Limits }\end{array}$ & Notes \\
\hline $\begin{array}{c}\text { Bounding Tank 42 } \\
\text { ESP Washwater } \\
\text { (Assuming a 1 wt.\% } \\
\text { insoluble entrained } \\
\text { solids concentration) }\end{array}$ & below 3E6 & - & $\begin{array}{c}\text { Source Term is } \\
\text { expected to be 10 } \\
\text { times lower }\end{array}$ \\
\hline $\begin{array}{c}\text { Influent Waste in } \\
\text { Double Contained } \\
\text { Transfer Lines }\end{array}$ & $2.3 \mathrm{E} 9$ & 770 & $\begin{array}{c}\text { All transfer schemes } \\
\text { are utilizing double } \\
\text { contained lines. }\end{array}$ \\
\hline $\begin{array}{c}\text { 242-16H Evaporator } \\
\text { Type IV Supernate }\end{array}$ & $1 \mathrm{E9}$ & 330 & $\begin{array}{c}\text { Source term for the } \\
\text { concentrated } \\
\text { supernate }\end{array}$ \\
\hline TE6 & $>1$ & $\begin{array}{c}\text { Source Term is } \\
\text { expected to be 10 } \\
\text { times lower }\end{array}$ \\
\hline
\end{tabular}

\subsection{Summary of Requirements}

- Temperature control for corrosion control purposes if transferred to Tank 43 and Tank 22.

- Vamp placement at Tank 42.

- Vamp placement within CST facilities if transferred to Tank 22.

- Transfer to Tank 22 will maintain $>18$ inches between the settling sludge interface and the transfer jet eductor.

- Divert storm water divertion gates in the affected zones. 


\section{Introduction}

As a result of the separation of the High Level Liquid Waste Department into three separate organizations [formerly there were two] (Concentration, Storage, and Transfer [CST], Waste Pre-Treatment [WPT] and Waste Disposition [WD]) process interface controls are required. One of these controls is implementing the Waste Acceptance Criteria and Waste Compliance Plan system for transfers of waste between CST and WPT. At present, CST's Waste Acceptance Criteria is undergoing revision and WPT has not prepared the required Waste Compliance Plan [WCP].

The Waste Pre-Treatment organization is making preparations for transferring spent washwater in Tank 42 to Tank 43 and/or Tank 22. The washwater transfer is expected to complete the washing steps for preparing ESP batch 1B sludge.

This report is intended to perform the function of a Waste Compliance Plan for the proposed transfer. Previously, transfers between the Tank Farm and ITP/ESP were controlled by requirements outlined in the Tank Farm's Technical Standards and ITP/ESP's Process Requirements. Additionally, these controls are implemented primarily in operating procedure 241-FH-7TSQ and ITP Operations Manual SW16.1-SOP-WTS-1 which will be completed prior to performing the waste transfers.

\section{Discussion}

The requirements for the Waste Compliance Plan [WCP] are outlined in the WAC (ref. 1). The first requirement of the WCP is to provide a description of the waste generating process that includes flowsheet information, transfer volumes, transfer frequencies and the transfer route. A description of the Extended Sludge process can be found in the HighLevel Waste System Process Interface Description (ref. 2) section 7. Therefore, a description of the waste generating process will not be part of this document. The proposed transfers from Tank 42 is expected to be the final ESP transfer to the evaporator system until sludge washing begins in Tank 40 for ESP Batch 2A in 1999.

Another requirement for the WCP is to provide a description and inventory of the chemicals and radionuclides used in the waste generating process. The waste generated in the ESP process is primarily contaminated water. The only chemicals used in the processing of waste in Tank 42 are sodium hydroxide and sodium nitrite and the trace impurities arriving with these chemicals which are also used by CST to prevent corrosion of their waste tanks. These chemicals can be added to the waste in the form of inhibited water or by direct addition from tanker trucks. The typical composition for these chemicals are provided in Appendix A. All other chemicals and radionuclides are received from CST's Tank Farm.

\subsection{The Waste Stream Categories and Characterizations}

The initial characterization of ESP decants to the H-Tank Farm is provided in Appendix B, stream number 560. The tables were taken from the Material Balance Tables for the DWPF Sludge Only Feed Flowsheet (ref. 3). Specific characterization of the sludge and 
supernate in Tank 42 can also be found in CST's Waste Characterization System (WCS) maintained by CST Engineering Support Group (ref. 4).

Based on the categories of waste described in section 7 of the WAC, the ESP decant is classified as an Irregular Waste (IW) because the concentration of compounds and isotopes from decant to decant varies, but the same species are present in each transfer.

\subsection{Compliance Strategy}

Corrosion prevention requirements are provided in the Tank Farm WAC and the Tank Farm Authorization Basis (AB) (ref. 5). Based on the Tank 42 ESP washwater chemistry the Tank Farm Technical Standards and the Tank Farm WAC are met. However, a maximum supernate temperature of $49^{\circ} \mathrm{C}$ will have to be maintained until the bulk chemistry is changed from influent transfers and diffusion of the existing supernate. Tank chemistry will also be verified by the governing operating procedures (i.e., 241-FH-7TSQ and SW-16.1-SOP-WTS-1 Manual, "Waste Transfer Approval and Route Review).

\subsection{Specific Criteria for Tank 42 Washwater Decant}

\subsubsection{Evaluation for the Hydrogen Generation Rate and the 242-16H Evaporator Radiological Source Term}

The Radiological Source Term (RST) for the evaporator is limited to $1 \mathrm{E} 9 \mathrm{rem} / \mathrm{gal}$ by the current AB. The RST for the Tank 42 washwater is less than 3E6 rem/gal (see Section 3.3.4) based on the $1 \mathrm{wt} . \%$ entrained solids. This value is approximately 300 times lower than the RST value for the evaporator. Concentration of this waste stream is not expected to impact the RST since it would require concentrating the waste stream by a factor of 300 which is incredible (due to the insoluble solids and solids content) in the Tank Farm Evaporator system. This is demonstrated by the RST for Tank 42 assuming a $1 \mathrm{wt} . \%$ sludge solids content having to concentrate to an incredible $300 \mathrm{wt} . \%$ solids to exceed the allowable evaporator RST.

The evaporator feed must also be limited to control the hydrogen generation rate below $1.2 \mathrm{E}-05 \mathrm{ft}^{3} \mathrm{H}_{2} /$ gal liquid waste/hr (8.98E-05 gal $\mathrm{H}_{2} /$ gal liquid waste/hr) within the evaporator. To impact the assumed evaporator feed $\mathrm{AB}$ hydrogen generation value (8.98E-05 gal $\mathrm{H}_{2} /$ gal liquid waste/hr) the $\mathrm{Pu}-238$ concentration ( $\mathrm{Pu}-238$ is the most restrictive radionuclide due to its high contribution to the dose potential) must be higher than $9.6 \mathrm{E}-01 \mathrm{Ci} / \mathrm{gal}$ (assuming $0 \mathrm{M}$ nitrate). This concentration is approximately 270 times greater than the $\mathrm{Pu}-238$ concentration in the Tank 42 washwater. Additionally, if the Tank 42 washwater actual isotopic distribution is considered in estimating the hydrogen generation it would require a solids concentration of $128 \mathrm{wt} . \%$ (refer to Appendix D) to equal 8.98E-05 gal $\mathrm{H}_{2} / \mathrm{gal}$ liquid waste/hr. It is incredible to achieve a concentration factor this high in the evaporator system due to the insoluble solids and solids content. Therefore, the bounding $\mathrm{AB}$ evaporator hydrogen generation rate criteria and the evaporator RST will not be exceeded. 
The time to the lower flammability limit (TLFL) was calculated for Tank 22 and Tank 43. Assuming the tanks were filled to the $\mathrm{AB}$ limit, it was determined that Tank 22 will remain a slow generating tank and Tank 43 will stay a rapid generation tank. Therefore, there is no expected impact to the TLFL Authorization Basis control requirements.

\subsubsection{Requirements for Corrosion Prevention}

Compliance to the Corrosion Prevention requirements are based on the latest available Tank 42 analysis. The sample was taken after completing sludge suspension with all four slurry pumps fully inserted. No additional sludge or other additions have been made to the tank since the sample was taken. Sample results are provided in Table 2 (page 14).

\subsubsection{Minimum $\mathrm{pH}$ of Waste $(\mathrm{pH}>9.5)$}

The latest analytical results for Tank 42 washwater are shown in Table 2 (page 14). The $\mathrm{pH}$ of this sample was 12.5 Therefore, the minimum $\mathrm{pH}$ requirement is met.

\subsubsection{Minimum Inhibitor Contents for all Waste Generators}

For hydroxide $\left(\mathrm{OH}^{-}\right)$concentration less than $1 \mathrm{M}$ and nitrate $\left(\mathrm{NO}_{3}{ }^{-}\right)$concentrations between $0.02 \mathrm{M}$ and $1.0 \mathrm{M}$, the WAC requires a minimum nitrite $\left(\mathrm{NO}_{2}{ }^{-}\right)$concentration of $1.66 *\left[\mathrm{NO}_{3}{ }^{-}\right]$. From Table 2 (page 14) the nitrate concentration is $0.05 \mathrm{M}$ and the nitrite concentration is $0.2 \mathrm{M}$. Thus the nitrite concentration is over four times the nitrate concentration and complies with the Tank Farm WAC.

Additionally, the ESP washwater nitrate and nitrite concentrations limit the maximum supernate temperature to $49^{\circ} \mathrm{C}$ for a Type III or a Type IV tank based on the Tank Farm Technical Standard (see calculation below). Complying with this requirement is not an issue since the supernate in Tanks 22,42 , and 43 is $21^{\circ} \mathrm{C}, 22^{\circ} \mathrm{C}$, and $29^{\circ} \mathrm{C}$, respectively. Transferring the washwater with a steam transfer jet will not result in a temperature increase above $49^{\circ} \mathrm{C}$, assuming a conservative temperature increase of $15^{\circ} \mathrm{C}$ and no heat loss.

Technical Standard Calculation:

$$
\mathrm{A}=0.038 *\left[\mathrm{NO}_{\overline{3}}\right] * 10^{\left(0.041^{*} \mathrm{~T}\right)}
$$

where;

$$
\begin{gathered}
\mathrm{A}=\left[\mathrm{NO}_{2}{ }^{-}\right] \\
\mathrm{T}=\text { temperature in }{ }^{\circ} \mathrm{C}
\end{gathered}
$$




$$
\mathrm{A}=0.038^{*}(0.05) * 10^{\left(0.041^{* 49)}\right.}, \mathrm{A}=0.19 \mathrm{M} \mathrm{NO}_{2}{ }^{-}
$$

At a temperature of $49^{\circ} \mathrm{C}$ and a nitrate concentration of $0.05 \mathrm{M}$, the minimum required nitrite concentration is $\sim 0.2 \mathrm{M}$.

If the washwater is sent to Tank 22, subsequent DWPF recycle waste transfers and diffusion/mixing of the existing DWPF recycle in Tank 22 will increase the allowable temperature. In the event the ESP washwater is sent to Tank 43, recycle transfers and diffusion of the existing supernate in Tank 43 will permit higher supernate temperatures. The next tank chemistry sample result will be used to evaluate the temperature limit.

\subsubsection{Maximum Concentration of Corrosive Species}

Table 4 (page 15) lists the corrosive species in the WAC, their maximum limit and the concentration in Tank 42's washwater. The CST's WAC maximum concentrations for corrosive species are not exceeded by the washwater.

\subsubsection{Requirements to Prevent Accumulation of Flammable/Explosive Species}

\subsubsection{Maximum $\mathrm{NH}^{+}$Concentration and Transfer Rate}

There are no sources for ammonium ion in the ESP wash water. Ammonium ion may have been originally introduced in the waste tank as ammonium nitrite and ammonium nitrate but the high $\mathrm{pH}$ maintained in the waste tank would have converted any ammonium ion to ammonia. Ammonia is volatile so it would have been already released (ref. 7) from the waste tank. Ammonium ion is not analyzed in ESP samples, but based on process knowledge, ammonium ion will be well below the limit given in section 13.2.2 of CST's WAC.

\subsubsection{Maximum Concentration of Organic Compounds}

Organic compounds are not added to Tank 42. Based on process knowledge, organic compounds in Tank 42 washwater will be well below the limit given in section 13.2.3 of CST's WAC.

\subsubsection{Prevent Formation of Shock Sensitive Compounds}

Silver is not added to Tank 42. Previous investigation have identified waste tanks that may contain shock sensitive compounds which did not include Tank 42 (ref. 7).

\subsubsection{Requirement For Radionuclide Content}

Source Term Criteria for Non Type IV Waste Tank

The specific source term criteria for Non-Type IV Waste Tanks is the composite inhalation dose potential concentration must be less than 2.3E9 rem/gallon (ref. 8). In addition, the solids inhalation dose potential concentration must be less than $4.5 \mathrm{E} 9$ rem/gallon (ref. 8).

The primary source of dose in ESP washwater (supernate) is soluble Pu-238. Other minor 
contributors for inhalation dose in the supernate phase are Sr-90 and Cs-137 (ref. 9). For Tank 42 sludge, the primary inhalation dose contributors are Pu-238, Cm-244, Am-241 and $\mathrm{Sr}-90$.

Normal analysis of washwater and supernate includes analysis of the significant inhalation dose contributors. Table 5 (page 16) lists the estimated concentration for these inhalation dose contributors in the washwater and the source for each estimate. Table 6 (page 16) lists the estimated concentration for the inhalation dose contributor and source of the estimate for Tank 42 sludge solids.

Determination of inhalation dose for wash water (supernate) is shown in Table 5 by multiplying each isotope concentration in $\mathrm{Ci} /$ gallon by the $\mathrm{Ci}$ to rem conversion factor and summing the rem for all the isotopes. A similar calculation is done for sludge in Table 6 .

During full operation of the slurry pumps $\sim 10 \mathrm{wt} . \%$ insoluble solids were suspended. A bounding source term for the washwater was determined by calculating the source term based on $1 \mathrm{wt} . \%$ insoluble solids in the washwater. This is $1 / 10^{\text {th }}$ the amount of insoluble solids in the slurry sample taken immediately after stopping all four slurry pumps on September 23, 1997 (after an extended sludge suspension run). The tank has remained as of December 5 undisturbed since October 3. Since Tank 42 has been allowed to settle for nine weeks, the suspended insoluble solids is expected to be $\sim 0.1 \mathrm{wt} . \%$ in washwater.

During ESP Process Verification testing in Tank 51, samples taken approximately 4 inches above the suspended solids/supernate interface contained less than $0.5 \mathrm{wt} . \%$ insoluble solids. This occurred 3 days after stopping the slurry pumps. By the earliest projected washwater transfer date of December 9, the tank will have remained in a quiescent period for at least 65 days. A clear supernate/sludge interface height measurement made after twenty-five days of settling has shown the insoluble solids level was 68 inches below the tank liquid level of $\sim 175$ inches. The latest turbidity reading shows that there are $>18$ inches between the supernate/sludge interface and the TTP eductor. The height of the transfer jet's eductor shall be set at least 6 inches above the clear liquid/ suspended solids interface for Tank 43 and $>18$ inches for Tank 22. The expectation is that the insoluble solids content in the washwater will be less than $0.1 \mathrm{wt} . \%$ solids (3E5 rem/gal). The bounding washwater source term was determined to be $3 \mathrm{E} 6 \mathrm{rem} / \mathrm{gal}$.

The rem/gal for the insoluble solids was calculated based on the 1992 Tank 42-25 Liter sludge sample which had a specific gravity of 1.17 and $22.1 \mathrm{wt}$.\% insoluble solids concentration (ref. 10). The inhalation dose potential for the insoluble solids is $6 \mathrm{E7}$ $\mathrm{rem} / \mathrm{gal}$.

The inhalation dose source term for both the washwater bounding case and insolubles are well below the limits in the "Draft" CST WAC Rev.2 (ref. 8) and ref. 13 for transfers to Tank 43. 
Required Concentration of Insoluble Solids in the Tank 42 ESP Washwater to Reach the Type IV RST Limit

The calculation below (see Appendix C) determined the maximum allowable insoluble solids concentration allowed in the washwater is $1 \mathrm{wt} . \%$. This calculation assumed the washwater RST (soluble phase) is negligible in comparison to the sludge RST since the sludge RST is 6E7 rem/gallon versus 3E5 rem/gallon for the soluble phase. Additionally, it conservatively assumes that any suspended solids that are transferred to Tank 22 do not settle. Settling is expected in Tank 22 as is demonstrated in Tank 42.

$$
\begin{gathered}
\frac{6 \mathrm{E} 7 \frac{\mathrm{rem}}{\text { gallon }} \text { insoluble solids }}{22.1 \mathrm{wt} . \%}=\frac{3 \mathrm{E} 6 \frac{\mathrm{rem}}{\text { gallon }} \text { insoluble solids }}{\mathrm{x} \text { wt.\% }} \\
\mathrm{x}=1 \mathrm{wt} . \% \text { insoluble solids }
\end{gathered}
$$

The Cs-137 concentration limit in the Technical Standard will not be exceeded since the Cs-137 concentration in Tank 42 is $0.01 \mathrm{Ci}$ /gallon (Table 2, page 14). This is a factor of 60 times below the Technical Standard limit.

\section{Source Term Criteria for Type IV Waste Tanks}

The Tank Farm Authorization Basis states that the supernate of Type IV tanks is limited to $3 \mathrm{E} 6 \mathrm{rem} /$ gallon and $<0.6 \mathrm{Ci}$ of $\mathrm{Cs}-137$ in the supernate (ref. 5,12). The Tank $42 \mathrm{ESP}$ wash water (supernate) will be acceptable to the Type IV AB since it is less than the 3E6 rem/gallon (or $<1 \mathrm{wt}$. \% entrained insoluble solids) and $0.01 \mathrm{Ci} /$ gallon Cs-137.

The washwater that will be transferred to the H-Tank Farm will have some entrained solids. During full operation of the slurry pumps $\sim 10$ wt. $\%$ insoluble solids were suspended. Since Tank 42 has been allowed to settle for nine weeks, the suspended insoluble solids is expected to be $\sim 0.1 \mathrm{wt} . \%$. During ESP Process Verification testing in Tank 51, a sample taken approximately 4 inches above the suspended solids/supernate interface contained less than $0.5 \mathrm{wt}$. \% insoluble solids. This occurred 3 days after stopping the slurry pumps (see discussion on page 8). The washwater transfer elevation is greater than 18 inches above the suspended solids/supernate interface (measured with a turbidity meter) for transfers to Tank 22 . The RST calculation below demonstrates that the bulk Tank 42 washwater would have to contain $1 \mathrm{wt} . \%$ insoluble solids before it would reach the RST limit for a Type IV waste tank. As mentioned above, the wt.\% insoluble solids is expected to be $\sim 0.1 \mathrm{wt} . \%$ which would correlate to a RST of $\sim 6 \mathrm{E} 5$ $\mathrm{rem} /$ gallon (3E5 rem/gallon from the washwater $+3 E 5 \mathrm{rem} / \mathrm{gallon}$ from entrained insoluble solids). Additionally no credit has been taken for blending with the existing Tank 22 supernate which has a very low RST. Waste transfers to Type IV waste tanks will maintain $>18$ inches between the solids/supernate interface and the transfer jet eductor. 
Source Term Criteria for Double Contained Transfer Lines

Double contained transfer lines have been evaluated for a inhalation dose potential concentration of $2.3 \mathrm{E} 9 \mathrm{rem} / \mathrm{gallon}$. The transfers lines between Tank 42 and 43 and between 42 and 22 all have double containment, therefore, they are limited to $2.3 \mathrm{E} 9$ $\mathrm{rem} / \mathrm{gallon}$. The ESP washwater will have a dose potential concentration below 3E6 $\mathrm{rem} / \mathrm{gallon}$ which is 750 times below the allowable. Therefore, the washwater is well below the limit for a double contained transfer line. It is recognized that the 3E6 rem/gallon requirement for the Type IV supernate dose potential must also be maintained.

Some small amount of drainback will occur to Pump Tank 3 after the Tank 42 to Tank 22 transfer. This drainback will be sent to Tank 38 through double contained transfer lines which is acceptable to the dose potential concentration limit of $2.3 \mathrm{E} 9 \mathrm{rem} / \mathrm{gallon}$. Additionally, this small amount of drainback will not effect the time to LFL for Tank 38, temperature limits, or require any VAMP compensatory measures due to the small volume associated with the drainback.

\section{Evaluation for the $\mathrm{H}$ Tank Farm Noncylindrical Valve Boxes}

The transfer line between Tank 42 and Tank 22 will be transferred through the Tank 22 noncylindrical valve box. The Tank Farm Authorization Basis does not allow high hydrogen generation material (i.e., fresh waste slurry, sludge slurry) to be transferred through the noncylindrical valve box due to the flammability potential. The ESP washwater is not classified as a high hydrogen generating material due to its low radionuclide content. Hence, it is acceptable to transfer through the Tank 22 noncylindrical valve box.

\subsubsection{Requirement for Regulatory Compliance}

No RCRA hazardous "listed" waste not exempted in Section 13.4 of the WAC [1] will be present in the Tank 42 washwater stream.

\subsubsection{Requirements for Criticality Safety}

Tank 42 contents including the washwater have previously been shown to be critically safe for any concentration and mass (ref. 9). The ratio of iron to $\mathrm{Pu}-239$, and $\mathrm{Mn}$ to $\mathrm{Pu}-239$ far exceeds the minimum ratios provided in the "Draft" WAC Rev.2 (ref. 8) based on the same criteria represented in reference 9.

\subsubsection{Requirement for Compatibility with the Tank Farm's Authorization Basis}

Approval of this transfer by the CSTE is acknowledgment that the waste characterization provided is sufficient for CSTE to recognize and evaluate any impacts on downstream processes. 


\subsubsection{Requirement to Satisfy Downstream Facility Acceptance Criteria}

Approval of this transfer by the CSTE is acknowledgment that the waste characterization provided is sufficient for CSTE to recognize and evaluate any impacts on downstream processes.

\subsection{ITP Detection of Leak from Valve-box by VAMP}

The amount of washwater and sludge that could leak before a VAMP would alarm was addressed in the Safety Evaluation (SE) for ESP (ref. 11). The calculation was based on a bounding source term and gamma dose for washwater and sludge. The calculation represents the bounding quantities of "Material at Risk" (radionuclides) for both off-site and on-site accidents. However, since the actual gamma dose constants for both sludge and washwater are less than the bounding term, the volume of liquid that could leak before a VAMP alarms exceeds the calculated volume.

The SE calculation was based on a VAMP located at a maximum distance of 50 feet from the source of a leak. For the proposed transfer, the only location for an above surface leak to occur is at the Tank 42 valve-box. A portable VAMP will be located at the valve-box during the transfer. Because the detection of radiation is inversely proportional to the square of the distance, a portable VAMP installed 1-meter from a potential leak site will detect a leak approximately $2.5 \mathrm{E} 3$ times smaller than at 50 feet. The gamma dose for the wash water is approximately $30 \%$ of the dose used in the bounding calculation for washwater. The bounding calculation determined the maximum release of washwater to be 75 gallons. By placing a VAMP at the valve-box it is conservatively estimated that no more than a gallon of washwater would leak before detected by the portable VAMP.

\subsection{H-Tank Farm Detection of Leak from Valve-box by VAMP}

An evaluation (ref. 14,15) was performed to ensure adequate protection is afforded by the ARMs to facility during the transfer of Tank 42 washwater. The transfer route for Tank 42 to Tank 43 is only above ground at the Tank 42 valve box. The review above addresses the Vamp issue for this transfer since the valve box is within the WPT facility. If the transfer route is to tank 22, then the route will include HDB-2, HDB-5, HDB-7, and the Tank 22 valve box. These containments are potential sites for a surface release. Based on the gamma inventory of the washwater, $0.01 \mathrm{Ci} / \mathrm{gal}$ of Cs-137, a spill of at least 140 gallons is required to activate an ARM 50 feet away. Given the stream dose potential, 3E6 rem/gal, the operator inhalation dose (from a 10 hour exposure at 10 feet from the spill) could exceed 4 rem. It is deemed prudent to provide ARM monitoring at the Tank 22 valve box. Vamps are already located at HDB-2, HDB-5, and HDB-7. Placement of Vamps closer to the leak site will allow detection at smaller volumes; for example, Vamps located within 10 feet of the spill will alarm with a spill $<10$ gallons.

The storm water divertion gates will be diverted in the affected zones. 


\section{References}

1. D. F. Brown and G. K. Georgeton, Waste Acceptance Criteria for High Level Liquid Waste Transfers to the 241-F/H Tank Farms (U), X-SD-G-00001, Rev. 1, March 29, 1995.

2. P. D. d'Entremont and et. al., High-Level Waste System Process Interface Description, WSRC-TR-0442, rev. 1, March 1995

3. A. S. Choi, Material Balance Tables for the DWPF Sludge-Only Feed Flowsheet (U), WSRC-91-542, Rev. 0, September 26, 1991.

4. J. R. Hester, High Level Waste Characterization System, WSRC-TR-96-0264, Rev. 0, December, 1996.

5. Technical Standard - Waste Tank Farms, DPSTS-241, Rev.2, February, 1992.

6. H-Area Tank Farm Technical Safety Requirements, WSRC-TS-96-13, rev. 1 December, 1996.

7. D. T. Hobbs, "Possible Explosive Compounds in the Savannah River Site Waste Tank Farm Facilities (U)," WSRC-TR-91-444, rev. 1, April 27, 1995.

8. M. E. Jamison, Waste Acceptance Criteria for High Level Liquid Waste Transfers to the 241-F/H Tank Farms (U), X-SD-G-00001, Rev. 2, (DRAFT).

9. J. S. Clemmons, "Nuclear Safety of Extended Sludge Processing on Tank 42 and 51 Sludge (DWPF Sludge Feed Batch 0ne) (U)," WSRC-TR-93-115, rev. 0, February 26, 1993.

10. M. S. Hay and N. E. Bibler, "Characterization and Sludge Washing Studies of Tank 42H Sludge (U)," WSRC-RP-94-730, July 27, 1994.

11. M. K. Gupta, "Safety Evaluation of the ESP Sludge Washing Baseline Runs and Sludge or Wash Water Transfers (U)," WSRC-TR-93-207, Rev 3, December 4, 1995.

12. WSRC-RP-94-0346, Revision 3, Basis for Interim Operation for Liquid Radioactive Waste Handling Facilities (U), 6/97

13.M. C. Chandler, HLW-HLW-96-0010, Canyon Receipts and Waste Acceptance Criteria, January 4, 1996

14.T. E. Britt, WSRC-TR-97-00401, Area Radiation Monitors: Adequacy and Strategy for Compensatory Measures, DRAFT 
WSRC-TR-97-00394

Page 13 of 29

15.NI-HLW-97-004, Area Radiation Monitoring for Low Gamma Waste Streams, $10 / 27 / 97$ 
Table 2. Tank 42 Slurry Sample Results, ESP-190

\begin{tabular}{|c|c|c|}
\hline Species & Result & Units \\
\hline SpG & 1.02 & g/mL, supernate \\
\hline NO2 & 0.20 & Molar (supernate) \\
\hline NO3 & 0.05 & Molar (supernate) \\
\hline OH & 0.03 & Molar (supernate) \\
\hline CO3 & 0.06 & Molar (supernate) \\
\hline SO4 & 0.01 & Molar (supernate) \\
\hline Cl & 0.001 & Molar (supernate) \\
\hline PO4 & 0.0002 & Molar (supernate) \\
\hline $\mathrm{Na}$ & 0.44 & Molar (supernate) \\
\hline pH & 12.5 & calc. from [OH-] \\
\hline Cs-137 & 2.9 & $\mu$ Ci/mL (or 0.01 Ci/gallon) \\
\hline & & \\
\hline Total solids & 13.1 & wt.\% of slurry \\
\hline Dissolved solids & 2.7 & wt.\% of supernate \\
\hline Soluble solids & 2.4 & wt.\% of slurry \\
\hline Insoluble solids & 10.7 & wt.\% of slurry \\
\hline SpG slurry & 1.09 & g/mL \\
\hline Fe & 18.4 & wt.\% dried solids \\
\hline Na & 9.4 & wt.\% dried solids \\
\hline $\mathrm{Al}$ & 7.0 & wt.\% dried solids \\
\hline $\mathrm{Mn}$ & 3.2 & wt.\% dried solids \\
\hline $\mathrm{Ca}$ & 2.3 & wt.\% dried solids \\
\hline $\mathrm{P}$ & 0.7 & wt.\% dried solids \\
\hline $\mathrm{Mg}$ & 1.1 & wt.\% dried solids \\
\hline $\mathrm{U}$ & 2.1 & wt.\% dried solids \\
\hline
\end{tabular}


Table 3. Tank 42 Washwater Analytical Results, ESP-191

\begin{tabular}{|c|c|c|}
\hline Species & Conc. & Unit \\
\hline $\mathrm{pH}$ & - & $\mathrm{N} / \mathrm{A}$ \\
\hline density & 1.02 & $\mathrm{~g} / \mathrm{mL}$ \\
\hline $\mathrm{C}_{2} \mathrm{O}_{4}{ }^{-}$ & 0.004 & $\mathrm{M}$ \\
\hline $\mathrm{SO}_{4}{ }^{-}$ & 0.009 & $\mathrm{M}$ \\
\hline $\mathrm{PO}_{4}$ & 0.0002 & $\mathrm{M}$ \\
\hline $\mathrm{Cl}^{-}$ & 0.001 & $\mathrm{M}$ \\
\hline $\mathrm{F}^{-}$ & 0.004 & $\mathrm{M}$ \\
\hline $\mathrm{NO}_{3}^{-}$ & 0.05 & $\mathrm{M}$ \\
\hline $\mathrm{NO}_{2}^{-}$ & 0.21 & $\mathrm{M}$ \\
\hline $\mathrm{AlO}_{2}^{-}$ & 0.004 & $\mathrm{M}$ \\
\hline $\mathrm{CO}_{3}{ }^{-}$ & - & $\mathrm{M}$ \\
\hline OH(Free) & - & $\mathrm{M}$ \\
\hline Total & 3.15 & $\mu \mathrm{Ci} / \mathrm{mL}$ \\
\hline Gamma & & \\
\hline $\begin{array}{c}\text { Dissolved } \\
\text { solids }\end{array}$ & 2.68 & Wt.\% of \\
\hline Fe (soluble) & 0.54 & $\mathrm{mg} / \mathrm{L}$ \\
\hline $\mathrm{Mn}$ (soluble) & $<0.015$ & $\mathrm{mg} / \mathrm{L}$ \\
\hline $\mathrm{U}$ (soluble) & 0.38 & $\mathrm{mg} / \mathrm{L}$ \\
\hline Pu & - & $\mathrm{mg} / \mathrm{L}$ \\
\hline
\end{tabular}

Table 4. CST's WAC Listed Corrosive Species Comparison

\begin{tabular}{|c|c|c|c|}
\hline Species & $\begin{array}{c}\text { WAC Max. } \\
\text { Limit }\end{array}$ & $\begin{array}{c}\text { Tank 42 } \\
\text { Washwater }\end{array}$ & $\begin{array}{c}\text { Below } \\
\text { Limit }\end{array}$ \\
\hline $\mathrm{Cl}^{-}$ & 0.11 & 0.001 & Yes \\
\hline $\mathrm{F}$ & 0.086 & 0.004 & Yes \\
\hline NO3 $^{-}$ & 8.5 & 0.05 & Yes \\
\hline SO4 $^{=}$ & 0.18 & 0.009 & Yes \\
\hline
\end{tabular}


Table 5. Tank 42 Inhalation Dose Species in Washwater

\begin{tabular}{|c|c|c|c|c|}
\hline Species & Ci/Gal & $\begin{array}{c}\text { Dose Factor } \\
(\mathbf{r e m} / \mathrm{Ci})\end{array}$ & $\begin{array}{c}\text { Dose } \\
\text { rem/gal. }\end{array}$ & Source of Reported Concentrations \\
\hline $\mathrm{Cs}-137$ & $1.1 \mathrm{E}-02$ & $3.2 \mathrm{E}+04$ & $3.5 \mathrm{E}+02$ & ESP-191 Sample \\
\hline $\mathrm{Pu}-238$ & $5.6 \mathrm{E}-07$ & $4.6 \mathrm{E}+08$ & $2.6 \mathrm{E}+02$ & ESP-183 Sample + WSRC-RP-94-730 \\
\hline $\mathrm{Pu}-239$ & $4.0 \mathrm{E}-08$ & $5.1 \mathrm{E}+08$ & $2.0 \mathrm{E}+01$ & ESP-183 Sample + WSRC-RP-94-730 \\
\hline $\mathrm{Pu}-240$ & $1.2 \mathrm{E}-08$ & $5.1 \mathrm{E}+08$ & $6.1 \mathrm{E}+00$ & ESP-183 Sample + WSRC-RP-94-730 \\
\hline $\mathrm{Pu}-241$ & $1.3 \mathrm{E}-06$ & $1.0 \mathrm{E}+07$ & $1.3 \mathrm{E}+01$ & ESP-183 Sample + WSRC-RP-94-730 \\
\hline $\mathrm{Pu}-242$ & $3.4 \mathrm{E}-11$ & $4.8 \mathrm{E}+08$ & $1.7 \mathrm{E}-02$ & ESP-183 Sample + WSRC-RP-94-730 \\
\hline Total & $1.1 \mathrm{E}-02$ & & $6.5 \mathrm{E}+02$ & \\
\hline
\end{tabular}

Notes: 1. Sample results reported in $\mu \mathrm{Ci} / \mathrm{mL}$ and converted to $\mathrm{Ci} / \mathrm{gal}$ by author.

2. Sample ESP-183 results reported as dpm/mL Total Pu converted to $\mathrm{Ci} / \mathrm{gal}$ for each isotope based on Tank $42 \mathrm{Pu}$ isotope distribution reported in WSRC-RP-94-730.

Table 6. Tank 42 Inhalation Dose Species in Sludge Insoluble Solids

\begin{tabular}{|c|c|c|c|c|}
\hline Species & $\begin{array}{c}\text { Ci/gram } \\
\text { insol. } \\
\text { solid } \\
\end{array}$ & $\begin{array}{c}\text { Dose } \\
\text { Factor } \\
\text { (rem/Ci) }\end{array}$ & $\begin{array}{l}\text { Dose (rem/g } \\
\text { insol. solids) }\end{array}$ & Source of Reported Concentrations \\
\hline Cs-137 & $1.8 \mathrm{E}-04$ & $3.2 \mathrm{E}+04$ & $5.8 \mathrm{E}+00$ & $\begin{array}{c}\text { "Composition. after } 4 \text { Cycles," Table 9, WSRC- } \\
\text { RP-94-730 }\end{array}$ \\
\hline Sr-90 & $6.2 \mathrm{E}-03$ & $1.3 \mathrm{E}+06$ & $8.1 E+03$ & $\begin{array}{c}\text { "Composition. after } 4 \text { Cycles," Table 9, WSRC- } \\
\text { RP-94-730 }\end{array}$ \\
\hline $\mathrm{Pu}-238$ & $8.1 \mathrm{E}-05$ & $4.6 \mathrm{E}+08$ & $3.7 \mathrm{E}+04$ & $\begin{array}{l}\text { "Centrifuge Tube 4," Table } 10 \& \text { "Composition } \\
\text { after } 4 \text { Wash Cycles," Table 9, WSRC-RP-94-730 }\end{array}$ \\
\hline $\mathrm{Pu}-239$ & $5.9 \mathrm{E}-06$ & $5.1 E+08$ & $3.0 \mathrm{E}+03$ & $\begin{array}{l}\text { "Centrifuge Tube 4," Table } 10 \text { \& "Composition } \\
\text { after } 4 \text { Wash Cycles," Table } 9 \text {, WSRC-RP-94-730 }\end{array}$ \\
\hline $\mathrm{Pu}-240$ & $1.8 \mathrm{E}-06$ & $5.1 \mathrm{E}+08$ & $8.9 E+02$ & $\begin{array}{l}\text { "Centrifuge Tube 4," Table } 10 \text { \& "Composition } \\
\text { after } 4 \text { Wash Cycles," Table 9, WSRC-RP-94-730 }\end{array}$ \\
\hline $\mathrm{Pu}-241$ & $1.9 \mathrm{E}-04$ & $1.0 \mathrm{E}+07$ & $1.9 \mathrm{E}+03$ & $\begin{array}{l}\text { "Centrifuge Tube 4," Table } 10 \text { \& "Composition } \\
\text { after } 4 \text { Wash Cycles," Table 9, WSRC-RP-94-730 }\end{array}$ \\
\hline $\mathrm{Pu}-242$ & $5.1 \mathrm{E}-09$ & $4.8 \mathrm{E}+08$ & $2.4 \mathrm{E}+00$ & $\begin{array}{l}\text { "Centrifuge Tube 4," Table } 10 \text { \& "Composition } \\
\text { after } 4 \text { Wash Cycles," Table 9, WSRC-RP-94-730 }\end{array}$ \\
\hline $\mathrm{Am}-241$ & $7.6 \mathrm{E}-06$ & $5.2 \mathrm{E}+08$ & $4.0 \mathrm{E}+03$ & $\begin{array}{c}\text { "Composition. after } 4 \text { Cycles," Table 9, WSRC- } \\
\text { RP-94-730 }\end{array}$ \\
\hline $\mathrm{Cm}-244$ & $1.5 \mathrm{E}-05$ & $2.7 \mathrm{E}+08$ & $4.0 \mathrm{E}+03$ & $\begin{array}{c}\text { "Composition. after } 4 \text { Cycles," Table 9, WSRC- } \\
\text { RP-94-730 }\end{array}$ \\
\hline Co-60 & $1.5 \mathrm{E}-06$ & $1.5 \mathrm{E}+05$ & $2.2 \mathrm{E}-01$ & $\begin{array}{c}\text { "Composition. after } 4 \text { Cycles," Table 9, WSRC- } \\
\text { RP-94-730 }\end{array}$ \\
\hline Eu-154 & $1.8 \mathrm{E}-05$ & $2.6 \mathrm{E}+05$ & $4.6 \mathrm{E}+00$ & $\begin{array}{c}\text { "Composition. after } 4 \text { Cycles," Table 9, WSRC- } \\
\text { RP-94-730 }\end{array}$ \\
\hline Eu-155 & $3.1 \mathrm{E}-06$ & $3.9 \mathrm{E}+04$ & $1.2 \mathrm{E}-01$ & $\begin{array}{c}\text { "Composition. after } 4 \text { Cycles," Table 9, WSRC- } \\
\text { RP-94-730 }\end{array}$ \\
\hline Total & $6.7 \mathrm{E}-03$ & & $5.9 \mathrm{E}+04$ & \\
\hline
\end{tabular}


WSRC-TR-97-00394

Page 17 of 29

5. Appendix A

Composition of Chemicals added to Tank 42 


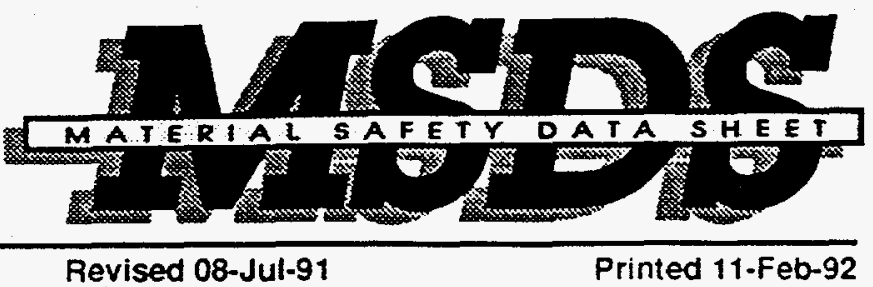

3740CR

Revised 08-Jul-91

Printed 11-Feb-92

\section{SODIUM NITRITE SOLUTION}

\section{MATERLAL IDENTIFICATION}

Corporate Number

Manufacturer/Distributor

Phone Numbers

Transport Emergency

Medical Emergency

Grade

Chemical Family

CAS Name

Du Pont Registry Number

Formula

TSCA Inventory Status
DU002807

Du Pont

1007 Market Stree

Wilmington, DE 19898

TECH: OXIDIZING SALT SOL. INORGANIC SALT SOLUTION

NITROUS ACID, SODIUM SALT

DP170-67-6

NaNO2 (in water)

Reported/Included

\section{\# COMPONENTS}

Material

CAS Number

Percent

TECHNICAL GRADE:

\begin{tabular}{lll}
\hline SODIUM NITRITE & $7632-00-0$ & 41 \\
\hline WATER & $7732-18-5$ & 59
\end{tabular}

OXIDIZING SALT SOLUTION:

\begin{tabular}{llc}
\hline SODIUM NITRITE & $7632-00 \cdot 0$ & 40 \\
\hline SODIUM CARBONATE & $497 \cdot 19-8$ & 2 \\
\hline SODIUM NITRATE & $7631.99-4$ & 10 \\
\hline WATER & $7732-18-5$ & 48 \\
\hline & & (continued)
\end{tabular}


ALIN : Gary Cook 704-399-5007

Shtp-to Customer so.: 90000682

CONTINENTAL INDUSTRIAL CHEMICALS; $C$

5010 HOVIS RD

CHARLOTTE-MECKIENBURG, NC 28208

United States
Quality Certificate/Shipping Info

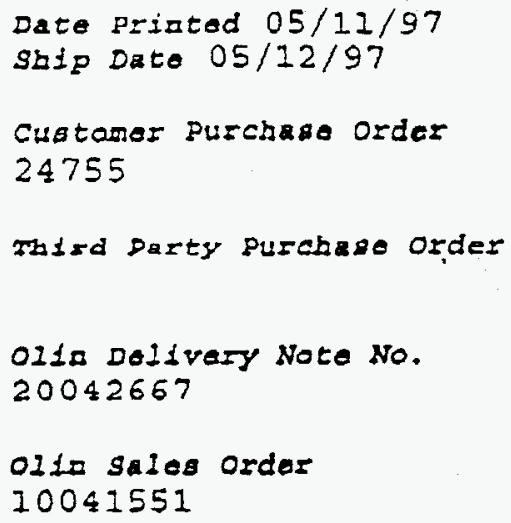

Haterial No. Deseription: Ol1a / Your reference 105016 Cauetic 50\% Rayon Grade /

$\begin{array}{llll}\text { Gross walght: } & 78,200.000 \mathrm{LB} & \text { Route/Carster: 50112/CTL Distribution } \\ \text { Net welght: } & 46,500.000 \mathrm{LB} & \text { Node: Truck } \\ \text { Soal No.: } & & \text { Vehfcie No.: } 21829 & 222\end{array}$

Olin Chlor Alkali Plants are ISO 9002 Certified under QSR100, 110,125 or 170 Inspection lot 29365 from 05/09/97 Inspection plan S_RAY162

\begin{tabular}{|c|c|c|c|c|}
\hline Characteristic & UnIE & value & $\begin{array}{l}\text { LoweI } \\
\text { Limit }\end{array}$ & $\begin{array}{l}\text { Upper } \\
\text { Limit }\end{array}$ \\
\hline
\end{tabular}

\section{$* *$ End ***}

The above analysis is certified to comply with olin/customer specifications (exceptions are noted above).

HARRY WADE

Olin Corporation

If your specifications have changed or if you received this document in ezro: please call 1-800-299-6546. 
WSRC-TR-97-00394

Page 20 of 29

\section{Appendix B}

Composition of Sludge Washing Decants

(Extracted from Ref. 3) 


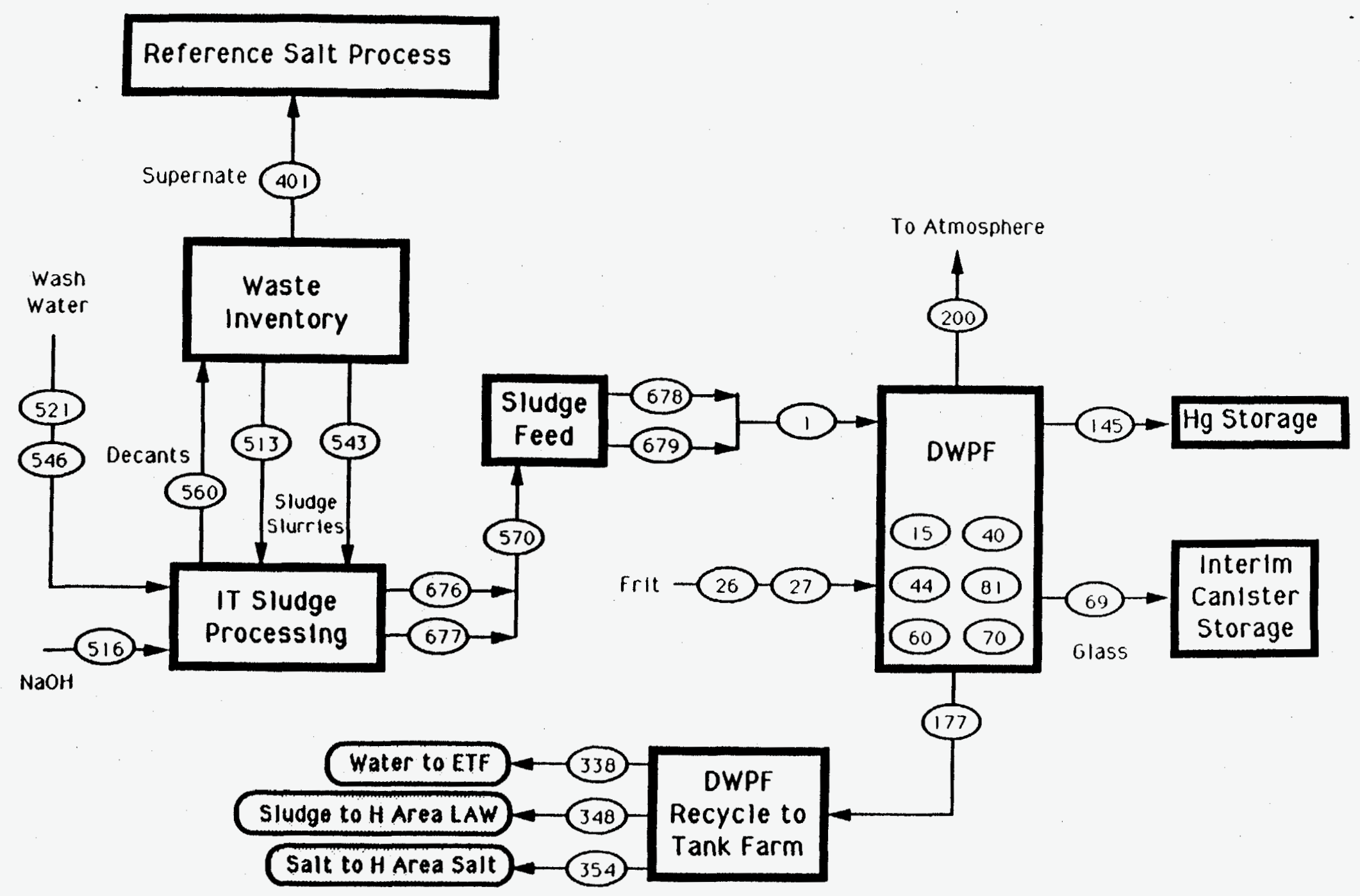

SECTION 0. MAJOR STREAMS IN THE SLUDGE-ONLY FEED FLOWSHEET MODEL 
STREAM NUMBERS -STREAM NAME

COMPONENT FLOWS, LB/HF $122($ C6HS) 2

123 ( $\mathrm{C} 6 \mathrm{HS}) 2 \mathrm{C} 6 \mathrm{H}$

110 (C6H5) 2NH

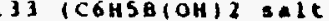

132 (С6HSQ(OH) 2 )

131 ICGHSOH SAlt

13O (C6HSOH)

$121(6646)$

ISS ( $\mathrm{CH} 3$ ) $2 \mathrm{CHOH}$

154 ( $\mathrm{CH}$ उOH)

$15 \mathrm{Ag}$

$116 \wedge 920$

134 AgNOJ

$\begin{array}{rl}77 & A 1203 \\ 106 & 0203\end{array}$

9 Ba (ОН)2

15 BaO

24 Baso

$66 \mathrm{co}$

$142 \mathrm{CO}(\mathrm{Cs})$

$63 \mathrm{Ca}(\mathrm{COOH})$

$120 \mathrm{CA}(\mathrm{OH}) 2$

20 cac20s

is cacos

$64 \operatorname{cocos}(\cos )$

$11 \mathrm{CaO}$

19 cesos

29 cerbon

99 cosent

$\begin{array}{ll}26 & \mathrm{COI} \\ 59 \mathrm{COO}\end{array}$

$90 \mathrm{C} \times 203$

12 c: 20

5) С $\mathrm{COOH}$

$96 \mathrm{CACl}$

CSOH

151 CATPa

$54 \mathrm{Cu}(\mathrm{COOH}) 2$

55 Cuo

100203

$101 \% 0$

102 Group A

$25 \mathrm{~Hz}$

258 $12 \mathrm{C} 204$

HSRC-TR-91-512 IROVISION
Table 1. DWPP sludge-Only Peed flowsheet Material Balence Tables

Soction 0, Table A $\rightarrow$. Major stroans in the Model Tables

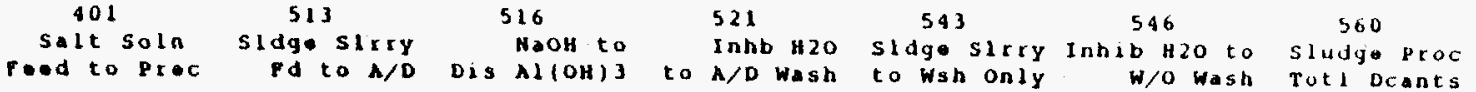

\begin{tabular}{|c|c|c|c|c|c|c|}
\hline $0.1413 E-10$ & ZERO & ZERO & ZERO & ZERO & zEro & ZERO \\
\hline & ZERO & ZERO & ZERO & ZERO & 2ERO & 2Eno \\
\hline $0.1826 E-15$ & 2820 & ZERO & ZERO & ZERO & 2EKO & ZERO \\
\hline ZERO & 2Eno & 2ERO & ZERO & 2ERO & ZERO & 2ERO \\
\hline ZERO & E8ro & ZERO & ZERO & ZERO & ZERO & ZERO \\
\hline $0.26185+01$ & 2ERO & ZERO & 2ERO & ZERO & ZERO & ZERO \\
\hline ZERO & ZERO & ZERO & 2ERO & ZERO & ZERO & ZERO \\
\hline $0.1986 E-09$ & 2ERO & ZERO & ZERO & ZERO & ZERO & ZERO \\
\hline $0.8493 E-09$ & 2ERO & ZERo & zERO & ZERO & 2ERO & ZERO \\
\hline $0.5300 z-10$ & Ixno & 2ERO & ZERO & $2 E R O$ & ZERO & ZERO \\
\hline ZERO & $2 \times 80$ & ZERO & ZERO & ZERO & ZERO & ZERO \\
\hline ZERO & $0.1939 x-02$ & 2ERO & 2ERO & $0.1091 E-01$ & ZERO & ZERO \\
\hline ZERO & IERO & ZERO & ZERO & ZERO & ZERO & ZERO \\
\hline ZERO & $0.1545 E+02$ & 2ERO & 2ERO & $0.47442+01$ & 2ERO & ZERо \\
\hline 2ERO & $85 \mathrm{xaO}$ & $28 \times 0$ & ZERO & $0.1667 E+00$ & 2ERO & 2ERO \\
\hline $0.17118+00$ & $0.1212 x-02$ & ZERO & ZERO & $0.1199 E-01$ & ZERO & $0.2014 E-01$ \\
\hline ZERO & $2 \Sigma \ln _{0}$ & zERO & 2ERO & ZERO & ZERO & ZERO \\
\hline ZERO & $0.11518+00$ & ZERO & ZERO & $0.2091 E+00$ & ZERO & 2ERO \\
\hline $0.1435 E-15$ & 2ERO & ZERO & ZERO & ZERO & ZERo & ZERo \\
\hline $0.22155-09$ & 2520 & EERO & zERo & ZERO & ZERO & ZERO \\
\hline $0.11125-18$ & 2Eno & 2ERO & ZERO & ZERO & 2ERO & ZERO \\
\hline ZERO & $2 \times 20$ & 2ERO & ZERO & ZERO & ZERO & ZERO \\
\hline $0.1430 E-01$ & $0.6765[-03$ & $2 E$ EHo & 2ERO & $0.9846 E-03$ & ZERO & $0.1653 E-02$ \\
\hline TERO & $0.54292-01$ & ZERO & ZERO & $0.1046 E+00$ & 2ERO & ZERO \\
\hline ZERO & $0.6977 \varepsilon+00$ & ZERO & ZERO & $0.3135 E-01$ & ZERO & ZERO \\
\hline 2280 & $0.58305+00$ & 2Eno & ZERO & $0.22928+01$ & ZERO & ZERO \\
\hline $2 E R O$ & $0.1369 x-06$ & ZEMO & ZERO & $0.98188-07$ & ZERO & ZERO \\
\hline ZERO & $0.10728-01$ & ZERO & ZERO & $0.1110 E+00$ & ZERO & ZERO \\
\hline $2 E 20$ & 2EAO & 2ERO & ZERO & $0.2074 E-01$ & ZERO & ZERO \\
\hline ECRO & $0.16312-01$ & 2ERO & ZERO & $0.2195 E+00$ & ZERO & ZERO \\
\hline 2ERo & $0.72438-02$ & 2EnO & ZERO & $0.9668 \mathrm{E}-01$ & ZERO & ZERO \\
\hline 2ERO & $\operatorname{seno}$ & $22 n 0$ & ZERO & 2E月O & $2 E$ HO & 2ERO \\
\hline 2ERO & ZERO & ZERO & ZERO & ZERO & ZERO & 2ERO \\
\hline EERO & $0.43028-03$ & 2820 & ZERO & $0.5004 \varepsilon-02$ & ZERO & ZERO \\
\hline 2ERO & $0.1007 x+00$ & $2 E R O$ & ZERO & $0.1739 E+00$ & ZERO & ZERO \\
\hline zeno & $0.6329 E-02$ & 2ERO & ZERO & $0.1126 E-02$ & ZERO & ZEHO \\
\hline 2880 & TERO & 2EnO & ZERO & ZERO & ZERO & ZEKO \\
\hline 2ERO & $2 \times 20$ & $2 E 80$ & 2ERO & ZERO & $2 E H O$ & ZERO \\
\hline $0.2515 E+00$ & $0.1066 E-01$ & ZERO & ZERO & $0.1552 E-01$ & 2ERO & $0.2606 E-01$ \\
\hline $2 E 90$ & ZERO & ZERO & ZEKO & ZERO & ZERO & ZEHO \\
\hline 2200 & $2 \varepsilon 80$ & ZERO & ZERO & ZERO & ZEHO & ZEHO \\
\hline 2ERO & $0.27625-01$ & 2ERO & ZERO & $0.0148 E-01$ & ZERO & ZERO \\
\hline ZESYO & $0.76=76+01$ & $2 \varepsilon 80$ & ZERO & $0.1731 \varepsilon+02$ & $2 E H O$ & ZERO \\
\hline ZERO & 2EHo & $2 E R O$ & ZERO & $0.3848 E-01$ & $2 E \times O$ & 2EHO \\
\hline $0.1403 E+00$ & $0.1400 \varepsilon+00$ & $2 E 80$ & 2E:HO & $0.4255 E-01$ & ZEHO & $0.1714 E-01$ \\
\hline $0.3582 E-03$ & $0.74476+00$ & 2ERO & ZERO & $0.1247 E+00$ & $2 E R O$ & $0.4142 E-04$ \\
\hline ZERO & TERO & 2ERO & ZERO & ZERO & ZEHO & ZERO \\
\hline 2ERO & ZERO & ZERO & ZEKO & 2ERO & ZERO & ZEHO \\
\hline
\end{tabular}


Tabl-1. DWPF Sludgo-only Feed Flowsheet Material Balance Tables

STREAM NUMBERs (CONT'D) STREAM NAME

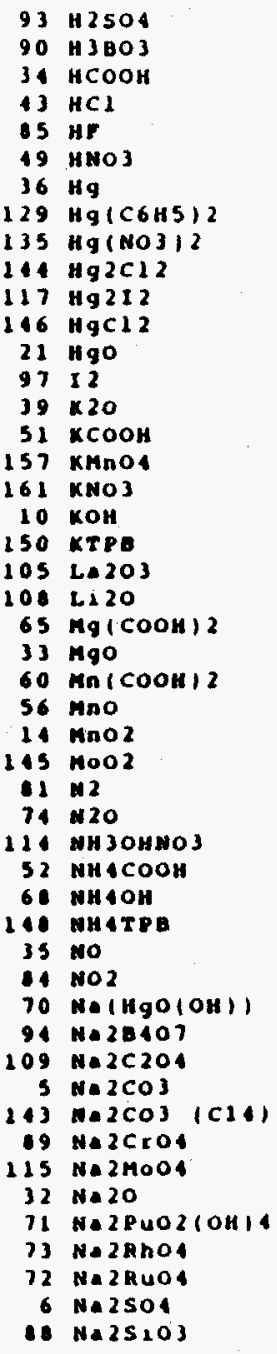

401

seit rood to proc

513

513

51dge $51 \times x y$ NaOH to $\begin{array}{lcc}521 & 543 & 546 \\ \text { Inhb H2O } 51090 \text { sirry Inhib H }\end{array}$ Pr EC
ZERO ZERO ZERO ZERO ZERO ZERO zEnO ZERO 2ERO ZERO IERO
ZERO ZERo TERO
ZERO zERO 2ERO
$0.9424 E+01$ zeno 2ERO ZERO 2Exo zero IERO ZERO $0.19312-08$ $0.3045 E-24$ $\operatorname{zeno}$

$0.35738+00$

$0.6199 \varepsilon-14$ $0.52898-20$

$0.03082+00$ $0.1314 \varepsilon+00$ $0.1804 \varepsilon+02$ $0.1862 E+03$
$0.1774 E-06$ $0.54318+01$ $0.1952 E+00$ ZERO $0.1618 E-03$ $0.26261 E-01$
$0.9707 E-01$ $0.2017 E+03$ $0.1739 E+01$

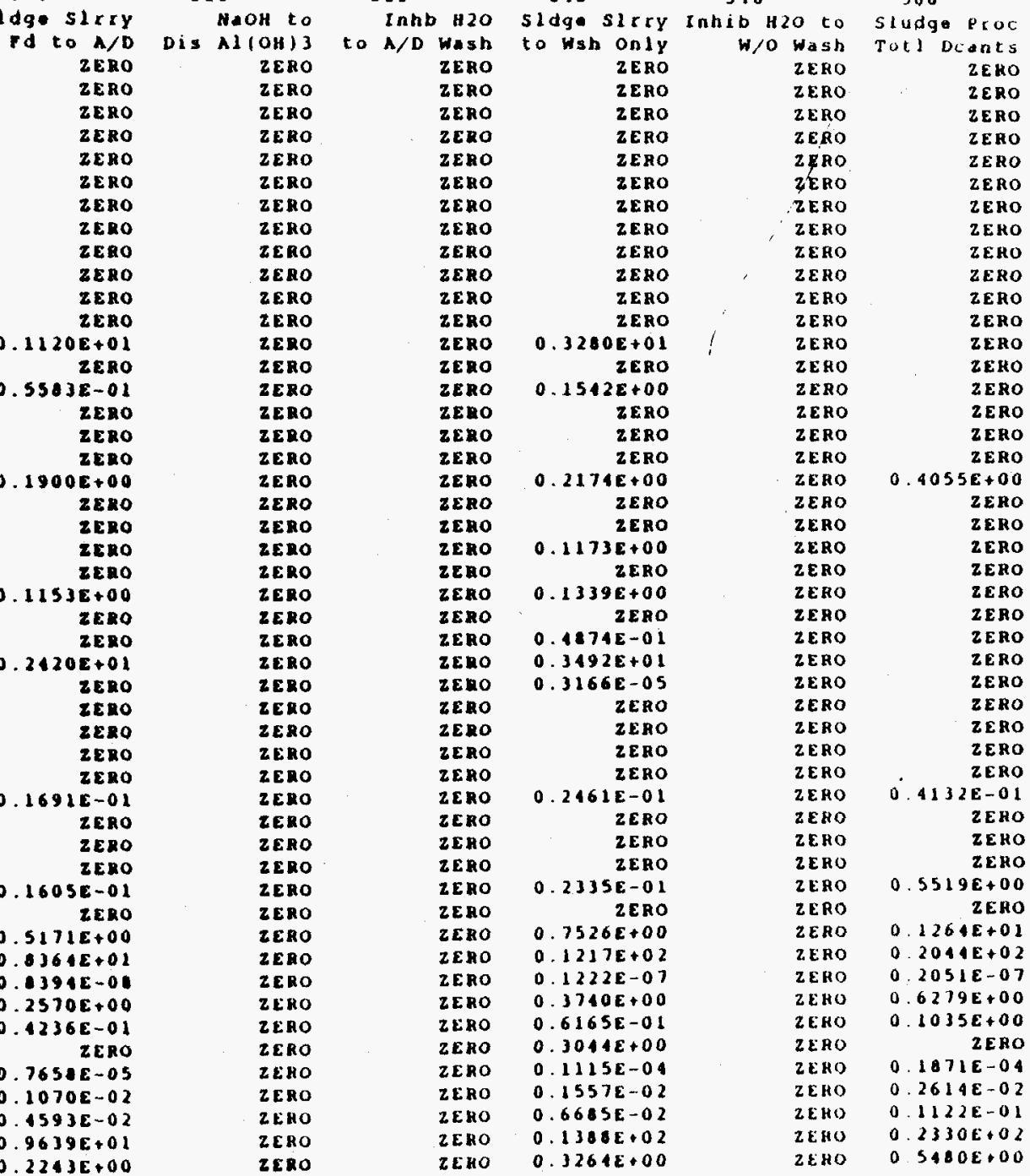

$0.2243 E+00$

ZEHO

Dete: Septenber 1991 
Tabl-1. DWPP sludge-only Fued flowsheat Material Balabce Tables

Section 0, Table A-7. Major Streams in the Model

STREAM NUMBERS $\{$ CONT'D $\rightarrow$ STREAM NAME

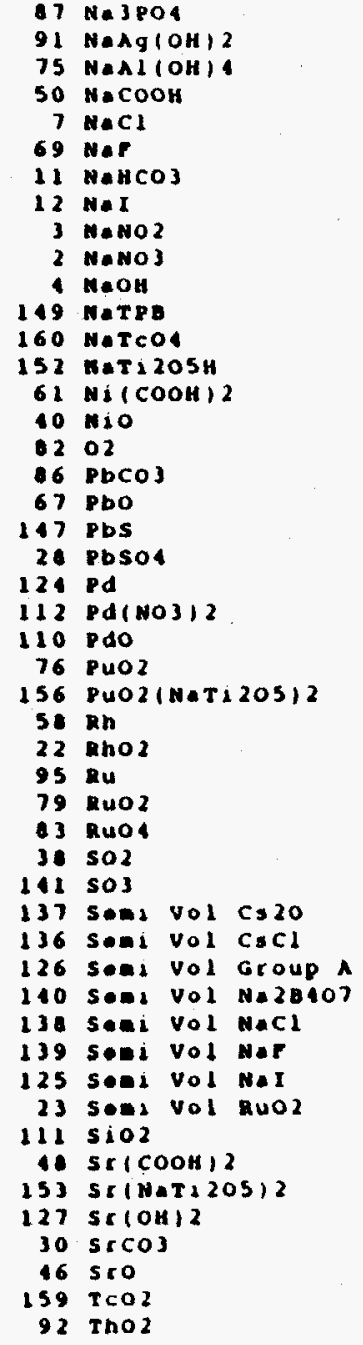


Tablo 1. DWPF sludgo-only Feed flowsheet Meterial balance tables

soction 0 , Tablo A-7. Major strames in the Modal

STREAM NUMBERS (CONT'D) STREAM NAME

107 TiO2

119 Tritiu

17 U308

62 UO2(COOH)

$16 \mathrm{UO} 2(\mathrm{OH}) 2$

$120 \mathrm{Y}(\mathrm{OH}) 3$

$328 \times(\mathrm{OH}) 3$

$17 \times 203$

100 20011te

$14 \mathrm{2n}(\mathrm{COOH}) 2$

$572 \mathrm{no}$

13 hydrate 20

13 hydreto

TOTAL FLOH, LB/HR

TEMPERATURE， DEG $C$

PRESSURE, ATM

PRESSURE, PSIG

PRESSURE， MH HG

ENTHALPY, PCU/HR

VAPOR ELOW, CYM

LRQUID FLOW, GPM
DENSITY, LBS/FT3

PHASE

401

salt soln 513

Fed to Prec
EERO
0.5967 E-06
ZERO

ldge $\operatorname{sic} x y$

516

Id to $A / D$

HaOH to

521

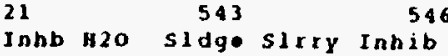

$0.21245-07$

$0.1143 \mathrm{E}+01$

$2 \times 80$

to $A / D$ Wash

1dge S1rxy Inhib g20 to sludgo Proc

ZERO

$0.1237 E-02$

$0.5856 E-04$

2ERO

ZERO

$0.4110 \mathrm{E}-07$

w/O wash

Totl Deants

ZERO

$0.5856 E-04$

ZERO

$\operatorname{2ERO}$

ZERO

2.no

$0.1012 E-05$

TERO

ZERO

$58-01$

$0.1646 E+00$

ZERO

zeno

$0.60175+04$

2ERO

$0.5546 E+03$

O. $7500 E+03$

$0.27685+02$

$0.4269 E+02$

$0.1000 E+01$
ZERO

2ERO

ZERO

TERo

zERO

ZERO

TERO

ZERO

2ERO

ZERO

0. $3637 E+02$

$0.11765+04$

$.1190 E+04$

0. $2500 \varepsilon+02$

$0.2500 E+02$

$1000 E+01$
ZERO

TOOOE+01
ZERO

zERo

$0.0522 E-04$

ZERO

$0.1473 E-05$

$0.7020 \mathrm{E}-02$

$0.16798-03$
$0.179 E+00$

ZERO

$0.1513 E+00$

$0.1676 E-01$
$0.9189 E+01$

$0.8174 E+03$

$0.1128 E+04$

$0.4095 E+02$

$0.1000 E+01$

ZERO

TERO

ZERO

ZERO

ZERO

ZERO

ZERO

ZERO

ZERO

ZERO

ZERO

ZERO

$0.25762+05$

$0.1200 \varepsilon+04$

$0.2958 E+05$

$0.37378+05$

$0.2500 E+02$

$\begin{aligned} \text { ZERO } & \end{aligned}$

$.69008-07$

ZERO

2ERO

C-05

TERO

ZERO

ZERO

ZERO

$0.3951 E+04$

$.3500 \varepsilon+02$

$0.1000 E+01$
ZERO

$0.1166 t+02$

$0.1265 E+01$

$0.74738+02$

$0.9513 E-01$

$0.953] E+02$

$0.23578+01$

$.6295 E+0$

LIQUTD

$0.2902 E+01$

$0.7399 E+02$

IIQUID

$0.4005 \varepsilon+05$

$0.1427 \varepsilon+0.6$

LIQUTO

LIOUIO

LTord

$.38298+01$

$295 E+02$
LIQUID

$6689 E+02$ LIQUID 
WSRC-TR-97-00394

Page 26 of 29

7. Appendix C

Determination of Wash Water and Sludge Inhalation Source Terms 
Inhalation Dose Source Term for Washwater Containing $1 \mathrm{Wt}$ \% Insoluble Solid Sludge

Grams insoluble solids/gal washwater $=$ wt.\% insolubles $* \mathrm{SpG}$ of slurry $* 3785 \mathrm{~g} / \mathrm{gal} / 100$

$=1 * 1.02 * 3785 / 100$

$=39$ grams $/$ Gal. of washwater

Inhalation Dose $=$ rem/gal liquid * gal liq/gal washwater + rem/gram insolubles * gram/gal washwater

$$
=6.5 \mathrm{E}+02 * 1+5.9 \mathrm{E}+04 * 39
$$

$=3 \mathrm{E}+06 \mathrm{rem} / \mathrm{gal}$

Inhalation Dose Source Term for insoluble solids in Settled sludge

Input $\mathrm{SpG} 1.17$

Wt.\% insoluble solids 22.1

Dose $(\mathrm{rem} / \mathrm{gal})=1.17 \mathrm{~g} / \mathrm{mL} \times 3785 \mathrm{~mL} / \mathrm{gal} \times 0.221 \mathrm{~g}$ insolubles/gram $\times 5.9 \mathrm{E}+04 \mathrm{rem} / \mathrm{gram}$ insol. solids $=6 \mathrm{E}+07 \mathrm{rem} / \mathrm{gal}$ 


\section{Appendix D}

Tank 42 Washwater Hydrogen Generation 


\section{Hydrogen Generation}

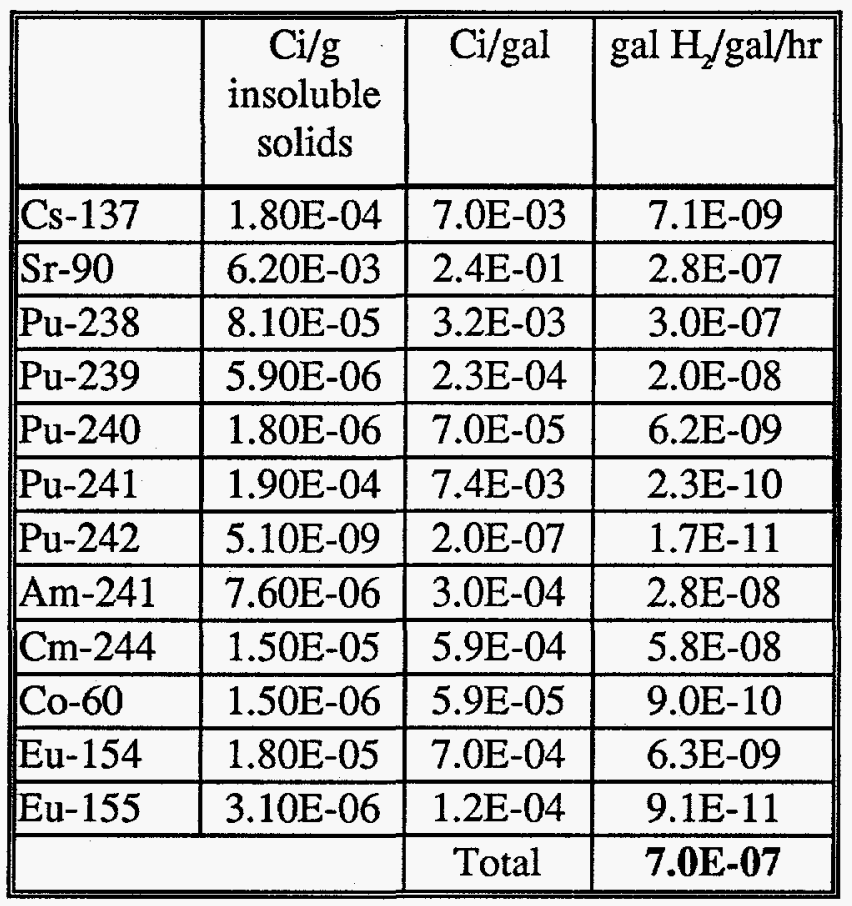

